NBER WORKING PAPER SERIES

\title{
THE IMPACT OF THE AFFORDABLE CARE ACT YOUNG ADULT PROVISION ON \\ CHILDBEARING, MARRIAGE, AND TAX FILING BEHAVIOR EVIDENCE FROM TAX DATA
}

\author{
Bradley Heim \\ Ithai Lurie \\ Kosali I. Simon \\ Working Paper 23092 \\ http://www.nber.org/papers/w23092 \\ NATIONAL BUREAU OF ECONOMIC RESEARCH \\ 1050 Massachusetts Avenue \\ Cambridge, MA 02138 \\ January 2017
}

The views expressed are those of the authors and are not necessarily those of the U.S. Department of the Treasury (USDT). We thank Angshuman Gooptu and Kate Yang for research assistance. The views expressed herein are those of the authors and do not necessarily reflect the views of the National Bureau of Economic Research.

NBER working papers are circulated for discussion and comment purposes. They have not been peer-reviewed or been subject to the review by the NBER Board of Directors that accompanies official NBER publications.

(C) 2017 by Bradley Heim, Ithai Lurie, and Kosali I. Simon. All rights reserved. Short sections of text, not to exceed two paragraphs, may be quoted without explicit permission provided that full credit, including $\odot$ notice, is given to the source. 
The Impact of the Affordable Care Act Young Adult Provision on Childbearing, Marriage, and Tax Filing Behavior: Evidence from Tax Data

Bradley Heim, Ithai Lurie, and Kosali I. Simon

NBER Working Paper No. 23092

January 2017

JEL No. I13,J12,J13

\section{ABSTRACT}

We use panel U.S. tax data spanning 2008-2013 to study the impact of the Affordable Care Act (ACA) young adult provision on two important demographic outcomes-childbearing and marriage. The impact on childbearing is theoretically ambiguous, as gaining insurance may increase access to contraceptive services, while also reducing the out-of-pocket costs of childbirth. The impact on marriage is also ambiguous, as marriage rates may decrease when young adults have less need for dependent health insurance through a spouse, but may increase when they are now allowed to stay on their parent's plans even if they are married. Changes in childbearing and marriage can, in turn, lead to changes in the likelihood of filing a tax return. Since W-2 forms record access to employer-provided fringe benefits, we were able to examine the impact of the coverage expansion by focusing on young adults whose parents have access to benefits. We compare those who are slightly younger than the age threshold to those who are slightly older. Our results suggest that the ACA young adult provision led to a modest decrease in childbearing and marriage rates, though the propensity to file a tax return did not change significantly.

Bradley Heim

School of Public and Environmental Affairs

Indiana University

1315 E 10th St

Bloomington, IN 47405

heimb@indiana.edu

Ithai Lurie

Department of the Treasury 1500 Pennsylvania Avenue NW

Washington, DC 20220

Ithai.Lurie@treasury.gov
Kosali I. Simon

School of Public and Environmental Affairs Indiana University

Rm 443

1315 East Tenth Street

Bloomington, IN 47405-1701

and NBER

simonkos@indiana.edu 


\section{Introduction}

As an early provision of the Affordable Care Act (ACA), insurers and sponsors of self-insured plans were required to allow dependents up to age 26 to remain on their parents' private health insurance policies. In this paper, we use U.S. tax data to examine whether providing a source of health insurance unconnected to their own employment affects childbearing and marriage: behaviors that are important in their own right, but also have implications for tax filing.

Prior to the reforms, young adults (generally defined as 19-25 year olds) were the most uninsured age group. Several studies have examined the insurance and medical care access effects of the ACA young adult (YA) provision, finding generally positive impacts. ${ }^{1}$ The resulting increase in health insurance coverage and access to health care may, in turn, affect childbearing and marriage behavior, though the expected direction of the effect is ambiguous.

Gaining access to coverage may increase the use of prescription contraceptives (Culwell and Feinglass (2007)), which may reduce or postpone childbearing (Miller et al. (2013)). However, health insurance coverage, and private health insurance coverage in particular, is associated with better prenatal care and birth outcomes (Oberg et al. 1991, Braveman et al. 1993, Currie and Gruber 1997, Kaestner 1999, Egerter et al. 2002), which may increase childbearing if young adults expect better prenatal care and more positive birth outcomes. On the other hand, DeLeire et al. (2011) find that Medicaid expansions for pregnancy coverage are not associated with increased childbearing. We are not aware of any published study that has examined the ACA YA provision's impact on childbearing. In concurrent working papers, Abramowitz (2016) examines childbearing using data from the American Community Survey (ACS) and the

\footnotetext{
${ }^{1}$ See, for example, Sommers et al. (2013), Akosa Antwi et al. (2013), and Barbaresco et al. (2015).
} 
National Survey of Family Growth (NSFG), and finds that the YA provision decreased the probability of childbirth and abortion, while increasing the use of long-term contraceptives, and Ma (2015) uses birth certificate data and finds that the provision decreased fertility rates but increased the share of children born to unmarried and less educated mothers.

Prior to the passage of the ACA, married children were generally not allowed on their parents' insurance plans (Levine et al 2011). The young adult provision of the ACA, however, allows young adults to stay on their parent's plans regardless of marital status; one might expect that the extension of coverage to married young adults might thus increase marriage rates among this population by reducing "non-marriage-lock." At least one study of a prior insurance expansion lends empirical support to such an expectation. Yelowitz (1998) finds that the expansion of Medicaid eligibility to married parent families not on AFDC led to a 1.7percentage-point increase in the probability of marriage. However, gaining access to health insurance coverage and health care might also lessen the incentive to get married. Several studies have documented the tight connection between health insurance and marital status, particularly for women (e.g. Peters et al. 2014, Lavelle and Smock 2012, Zimmer 2007). If the ability to gain coverage through a potential spouse might be a positive incentive to marry, ${ }^{2}$ access to dependent coverage through a parent instead would weaken the marriage incentive. Further, access to birth control has been found to lead to delay in marriage (Goldin and Katz 2002 and Abramowitz 2014); an expansion of health insurance that covers such services might lead to a decline in marriage among young adults. Delayed marriage has been shown to improve welfare: Dahl (2010) shows that delayed marriage causes lower incidence of poverty at later ages for women;

\footnotetext{
${ }^{2}$ Indeed, in a 2008 Kaiser Family Foundation survey, 7 percent of respondents said they or someone in their household married in the past year "mainly to have access to [their] spouse's health care benefits" or "mainly so [their] spouse could have access to [their] health care benefits," though, as is noted in Kaiser Family Foundation (2008), the 7 percent figure is almost certainly a gross overestimate of the fraction of the population that marry for health-insurance-related reasons.
} 
Mincy et al. (2009) find no evidence, however, that marriage itself increases the earnings of lowincome fathers. Decker (2000) finds that the introduction of Medicaid, which made health insurance available to single mothers, led to a 0.3 -percentage-point increase in the probability that a woman was a single mother with young children. Further, Abramowitz (forthcoming), in the study most closely related to this one, uses American Community Survey data to examine the impact of the ACA young adult provision on marriage, and finds that the provision led to a decrease in the likelihood of marriage.

Changes in childbearing and marriage can, in turn, lead to changes in the likelihood of filing a tax return. Numerous tax code provisions reduce taxes owed for those with children, including dependent exemptions, the Child Tax Credit, the Earned Income Tax Credit, and the Child and Dependent Care Credit. Since claiming these benefits requires filing of a return, an increase in childbearing may lead to an increase in filing and vice versa. However, if childbearing is also associated with lower labor supply and earnings, filing may decline. The tax-filing impact of marriage is also ambiguous, and depends on the incomes of the spouses relative to the filing thresholds. ${ }^{3}$

In this study, we use tax data spanning 2008-2013 to estimate difference-in-differences models of childbearing and marriage, comparing 24-25 year olds who were affected by the YA provision to 27-29 year olds who were not. We make four novel contributions. First, we use administrative data, which is less subject to misreporting than survey data. Second, we focus on those whose parents are likely to have employer sponsored insurance (ESI) and so are affected

\footnotetext{
${ }^{3}$ The filing threshold for married couples is twice the amount for singles. As a result, if a woman who is just above the single filing threshold marries a man who has no earnings, the marriage would place the couple below the married filing threshold, and they would not be required to file a return. On the other hand, if a man who earned more than the married filing threshold married a woman who was below the single filing threshold, the marriage would lead to the woman being required to file a return.
} 
by the reform. Third and fourth, we estimate effects separately by schooling status, and by parental socioeconomic status.

We find that the YA provision reduced childbearing among young women, particularly among the unmarried, those with fewer than two prior children, and those not in post-secondary school. In addition, we find that the YA provision led to a decline in marriage among 24-25 year olds, which is consistent with Abramowitz (forthcoming). However, we find little effect on the propensity to file a tax return.

\section{Data}

We draw a sample from the population of U.S. federal tax documents that spans 2008-2013. Using an existing tax data file from 1997 linking the Social Security Numbers (SSNs) of primary and secondary filers to the SSNs of their dependent children, ${ }^{4}$ we match the parents' information from W-2 forms filed in 2008-2013 to their children's information on childbearing, marriage, income, and other demographic variables from those same years. ${ }^{5}$ Because individuals older than 18 years in 1997, or born after 1995, were less likely to be claimed as dependents in 1997, we utilize information on birth cohorts from 1979 through 1995. This structure limits our pre-

\footnotetext{
${ }^{4}$ Almost all children below 19 are likely claimed on a parent's tax returns, especially given the substantial tax benefits of claiming children. The dependent file based on claiming behavior is comprehensive in tax year 1997 and in 2001 and forward, but is very limited prior to 1997 and in 1998-2000.

${ }^{5}$ If the parents divorced between 1997 and the 2008-2013 period, we are still able to match the W-2 information from both parents to the young adult. However, if one of the parents married or remarried, and the new spouse provided a source of health insurance coverage for the young adult, we would miss such coverage.
} 
trends tests to 2008-2009, as we cannot go back further than tax year 2008 and still have the full set of control individuals of ages $27-29 .^{6}$

We use information from Social Security Administration and tax records to measure childbearing. Our preferred measure of childbearing uses a Social Security Administration file to identify the date of birth for children of any of the young adults in our sample. Working backwards from the birth date, we create a variable denoted "conception assuming full term," which indicates whether the young woman conceived a child in a particular year, assuming that the newborn was born after a full-term, 9-month, pregnancy. ${ }^{7}$ This variable is available regardless of whether a young adult files a tax return, and it treats the timing of control and treatment periods correctly, as any births in a particular year should be influenced by policies in place before conception as well as during pregnancy. As a robustness check, however, we also use birth in a given tax year as the dependent variable.

As an alternative measure, we utilize the fact that tax data contains the Social Security Number of any child claimed as a dependent of a taxpayer in a particular year. Using a file provided by the Social Security Administration, we merge the birthdate of each child, and identify a newborn by whether the taxpayer had a child in that tax year. This is, however, limited to tax filers.

For our marriage outcome variable, we utilize information reported on Form 1040. We consider an individual married if his or her filing status is married filing jointly or married filing

\footnotetext{
${ }^{6}$ Since our oldest cohort was born in 1979, prior to 2008, this cohort was younger than 29.

${ }^{7}$ To the extent that pregnancies were less than full term, this variable may wrongly assign conceptions in the treatment period to the earlier control period, which would tend to bias our estimate downward. A similar bias arises if time of birth is used to assign treatment and control periods, since some conceptions that occurred in the control period would be treated as if they occurred in the treatment period.
} 
separately. Note again, that this information is only available if the individual files a tax return. In our main marriage specifications, we include all young adults, both men and women.

Ideally we would know parental ESI information for each year of our data. However, the IRS employer requirement for reporting ESI started in 2012, and only for firms with over 250 workers. ${ }^{8}$ We thus also use parental employer-based retirement plans (available in all years) to proxy for ESI. Tabulations from the CPS and the MEPS suggest that more than $90 \%$ of families in which at least one parent contributes to a retirement plan are also covered by ESI, which suggests validity of the proxy measure. As around $20 \%$ of families in the MEPS without employer-sponsored retirement are covered by ESI, not contributing to a retirement plan is a weaker proxy for lack of health insurance.

We also pull a set of demographic information from the young adults' and parents' tax records, including marital status (from Form 1040), post-secondary attendance (from Form 1099T), and parental income (from the parents' Form 1040).

In our main specifications, we only include young adult women; male health insurance access is unlikely to affect the contraceptive use or pregnancy behavior of their partners.

We use a $1 \%$ random sample from the parent-child matched population for our analysis. When we limit to 24-29 year olds, excluding 26 year olds and using all data from 2008-2013 except 2010, we obtain 401,922 person-year observations in our female sample. ${ }^{9}$ Table 1 presents sample statistics for two samples - females of ages 24-29, and females of ages 24-29

\footnotetext{
${ }^{8}$ Approximately $40 \%$ of the US workforce is employed by firms with fewer than 250 workers. (From https://ycharts.com/indicators/total_nonfarm_payrolls).

${ }^{9}$ We examined our sample by year and age and observed that the number of individuals does not change in any systematic way over time as we construct a balanced panel, except that the number of older-age individuals is consistently lower than those of younger ages, likely due to 17 and 18 year olds being more likely to have left the parental household in 1997. We found no evidence of systematic difference in sample size that would affect our identification method (for example, between treatment and control, before and after the policy).
} 
whose parents participated in a retirement plan. Around 9 percent report a newborn in a given year, though the fraction is slightly lower when we limit to those whose parents contributed to a retirement plan and so were likely to be covered by ESI.

\section{Method}

We initially estimate the impact of the YA provision with a simple difference-in-differences (DD) specification. We compare those in the treatment ages (24-25 year olds) to those outside the treatment ages (27-29 year olds), before and after the law. We exclude 26 year olds ${ }^{10}$ as they are likely to have been in both the treatment and control groups in the prior year.

We estimate an equation of the form

$$
\text { Outcome }_{i t}=\beta_{1} \text { Young }_{i t}+\beta_{2} \text { Young }_{i t}{ }^{*} \text { Post }_{i t}+\delta_{t}+\varepsilon_{i t}
$$

where Outcome $_{i t}$ denotes either childbearing, being married or filing taxes, Young ${ }_{i t}$ denotes being age 24-25, Post $_{i t}$ denotes the year being 2011-13, and $\delta_{t}$ is a year fixed effect. ${ }^{11}$ The coefficient of interest is $\beta_{2}$.

We next conduct regression-adjusted versions of the DD calculations in which we account for the national annual unemployment rate, age fixed effects, and an interaction between the two. As these estimates may still mask causal effects that occur only among those whose parents have ESI, our preferred DD model focuses on young adults with such parents.

\footnotetext{
${ }^{10} \mathrm{We}$ only exclude 26 year olds in the year in which they turned 26 . These individuals are included in the sample in other years under analysis.

${ }^{11}$ Note that we do not include state fixed effects, as we cannot observe state of residence for young adults who do not file a tax return and do not receive a W-2 or 1098-T form.
} 
In all specifications, we exclude 2010 as a period of staggered implementation; some insurers complied as early as spring 2010 , but as most insurance plans renew on January $1^{\text {st }} 2011$, we consider that the full implementation date.

To verify that our estimates are not driven by differential pre-existing trends between the treatment and control groups, we test whether time trends in childbearing and marriage differed between the treatment and control groups in our limited set of years prior to the policy change. Reassuringly, the difference in pre-policy trends is not statistically significant for any of the specifications. $^{12}$

As a further specification test, we examine whether parental ESI (as proxied by parental participation in a retirement plan) was affected by the ACA. If access was affected, the composition of treatment and control groups could be endogenous to the reform. However, in a DD model with parental health insurance as the dependent variable, the estimated impact was small and statistically insignificant. ${ }^{13}$

\section{Childbearing Results}

\subsection{Main Estimation Results}

\footnotetext{
${ }^{12}$ In the pre-trends tests for our preferred specifications in Column 3 of Table 2, the coefficients (st. errors) on Treatment*PlaceboPost were $0.000(0.005)$ in the Conception Assuming Full Term in SSA Data specification, $0.001(0.005)$ in the Newborn in SSA Data specification, $-0.002(0.005)$ in the Newborn in Tax Data specification, and 0.006 (0.007) in the Tax Return Filer specification. Abramowitz (2016) performed similar tests using a longer pre-reform period, and also could not reject equality of trends. The levels are, however, different, with $5.2 \%$ of the control group (24-25 year olds) conceiving a child in 2009, as compared to $7.2 \%$ of the treatment group (27-29 year olds).

${ }^{13}$ The estimated coefficient was actually negative at -0.001 , with a standard error of 0.002 .
} 
Table 2 presents the results from our main specification. In Panel A, the dependent variable indicates whether a conception occurred that resulted in a live birth, full-term, pregnancy. In Column 1, we present results from a simple DD specification; the estimated coefficient suggests that the YA provision decreased childbearing by 0.4 percentage points, and this coefficient is marginally statistically insignificant. When adding controls in Column 2 , the result remains a decline of 0.4 percentage points, and is now highly statistically significant. In Column 3, we cut the sample to those who are likely to be "treated" by the YA provision by including only those whose parents have an employer-based retirement plan. In this preferred specification, the estimated impact of the YA provision increases slightly to a 0.5 percentage point decline (from a base of 7.7 percentage points, for a decrease of $6.5 \%$ ), and is still highly statistically significant. This reduction would amount to a decrease of around 4,500 births annually. ${ }^{14}$

To examine the robustness of these results to alternative definitions of childbearing, we change the timing of the dependent variable to be the birth (rather than conception) of a child in the SSA data in Panel B and the presence of a newborn in tax data in Panel C. Since the timing of these variables is not exact, one would expect the estimates to be biased downward. This is indeed the case, as the estimated coefficients in the third column are smaller in magnitude (0.002 and -0.003 ) than in our preferred specification, and marginally statistically significant. Since the dependent variables in Panel $\mathrm{C}$ is only observed when a woman files a tax return, one might be concerned that if the young adult provision affected filing behavior, this change in the sample might impact our estimates. Therefore, in Panel D we estimate the impact of the YA

\footnotetext{
${ }^{14}$ The sample in this specification includes 93,170 young adults who are 24-25 years old, who represent 9,317,042 individuals given our $1 \%$ sampling rate. Thus, a 0.5 percentage point decline (assuming singleton births) is 46,585 fewer births. Since these are short run effects, it is not possible to know whether these are simply delayed births or reductions in completed fertility.
} 
provision on tax return filing. Although we find a significant increase in the DD specification with controls, in the other two specifications the impact is small and insignificant, suggesting that those results are likely not significantly impacted by policy-driven changes in filing behavior.

Taken together, these results suggest that the YA provision led to a decline in childbearing among the targeted population.

\subsection{Alternative Treatment Group}

To examine the robustness of our preferred estimates to include younger cohorts in our treatment group, we expanded the estimation sample to 19-29 year olds. These results are presented in Table 3. When 19-23 year olds are added to the treatment group, which now includes those age 19-25, the impact on childbearing remains negative and statistically significant, but now somewhat larger, with the YA provision estimated to have decreased the propensity to have a child by 0.7 percentage points (or $11.1 \%$ compared to a base of 6.3 percentage points). These results could reflect that younger women's usage of contraceptive services may be more price sensitive, leading to larger reaction, and thus an even greater decline in childbearing.

\subsection{Results for Subsamples}

To examine whether the impact of the YA provision differed according to young adults' demographic characteristics, in Table 4 we re-estimate our preferred specification using a sample 
of young adult men. We also split the sample according to the income of the young adult's parents in 1997. Column 1 again presents the results from our preferred specification.

In Column 2, when a sample of young men is used for the estimation, the estimated coefficient for young men is smaller than that for young women, and is statistically insignificant. ${ }^{15}$ This is consistent with the expectation that the YA provision would primarily impact childbearing through young women gaining access to their parents' insurance.

In Columns 3 and 4, we split the sample according to whether the young adult's parents' income in 1997 was lower or higher than the median income (approximately 250\% of FPL). Splitting the sample according to parental income is preferable to splitting according to the young adults' income, as parental income is likely to closely correlate with the young adult's socioeconomic status (SES), while the young adult's income may differ substantially from their SES while in school or starting out at a job. These specifications do not reflect much of a difference across income groups, with childbearing reduced by similar magnitudes in the two income groups (-0.006 vs. -0.007 percentage points).

Finally, in Table 5, we estimate effects by marital status, by birth parity, and by enrollment in post-secondary education. ${ }^{16}$ Since childbearing behavior tends to differ by marital status, estimating different effects by marital status is a natural extension. However, Abramowitz (forthcoming) finds that the YA provision reduced marriage among the affected ages, and so these groupings may be endogenous to the policy being studied. Table 5 results suggest that the decline in childbearing was steeper among unmarried young adults (with no significant effect for those married), those who already had one child (with a smaller effect

\footnotetext{
${ }^{15}$ However, the $95 \%$ confidence intervals of these two coefficients overlap

${ }^{16}$ Enrollment in post-secondary education is observed through the issuance of a Form 1099-T - Tuition Statement for the young adult by a post-secondary institution. It measures enrollment at some point during the tax year.
} 
among those with no children, and no effect among those with two or more children), and those who were not in post-secondary school. Given the findings in Abramowitz (forthcoming), an alternative interpretation of the steeper decline among unmarried women could be that the YA provision led young women who were not planning to bear a child to stay single, decreasing the childbearing rate among this group.

\section{Marriage and Tax Filing Results}

Panel A of Table 6 presents the main results for the probability that an individual is married in the tax data, with the first column presenting the estimate from a simple difference-indifferences, the second presenting results from a difference-in-differences that includes covariates, and the third presenting results when the sample is cut to those likely to be treated. The estimated coefficient is negative in all three specifications but is only significant in the third, suggesting that including those who were not likely to be treated resulted in downward-biased estimates. This coefficient implies that the YA provision decreased the propensity to be married by 0.5 percentage points, from a base of $23.9 \%$.

We only observe whether a young adult is married if the individual files a tax return, and so the result may be biased if the policy impacted the propensity to file a tax return. In Panel B, the dependent variable suggests that the YA provision led to a statistically significant increase in filing among all young adults. Since nonfilers are more likely to be single, this would suggest 
that our estimated impact on marriage may be biased upward toward finding more of an impact. $^{17}$

Table 7 presents results from adding 19-23 year olds to the treatment group. We treat these results cautiously because of concerns related to the parallel trends assumption in marriage rates for this age group relative to the control group. When this age group is added in Column 2, the impact on marriage switches sign. In this specification, the YA provision is estimated to have increased the likelihood of marriage by 0.8 percentage points. The rationale for this change in sign could be the following. Prior to the YA provision, 19-23 year olds could have stayed on their parents' plans if they were students, so long as they remained unmarried. The YA provision, then, primarily would have enabled these individuals to stay on parental plans even while married, which would lead to an increase in marriage. 24-25 year olds, however, could not stay on their parents' policies (married or not) prior to ACA. For these young adults, the YA provision primarily reduced the need for spousal health insurance, thus reducing the propensity to marry.

To examine whether the impact of the YA provision on marriage differed according to demographic characteristics, in Table 8 we re-estimate the preferred specification while splitting the sample according to whether the young adult is male or female and by income.

In Columns 1 and 2, the direction of the YA provision's impact on marriage is the same for both genders, but the YA provision is estimated to have a larger impact on marriage for men (a 0.6-percentage-point decrease compared with 0.3 percentage points for women).

\footnotetext{
${ }^{17}$ If the YA provision led additional people to file a return, and those people are more likely to be single, then the sample post-policy would tend to have fewer married taxpayers, which would be reflected in a negative coefficient.
} 
In Columns 3 through 6 , when the sample is split according to parental income, the largest (and statistically significant) impacts on marriage are centered on the two middle-income

groups. It may be that these groups tend to be closer to the margin of deciding whether or not to marry, and so the availability of health insurance from someone other than a spouse is more likely to lead these individuals to delay getting married.

Overall, our results suggest that the ACA YA provision led to a decrease in marriage among 24-25 year olds, which is consistent with the findings in Abramowiz (forthcoming).

\section{Conclusion}

There is very little evidence prior to the ACA regarding how access to health insurance affects the demographic outcomes of young adults. Tax data provide a unique opportunity for estimating the impact of the ACA YA provision on childbearing and marriage using a large sample of administratively reported data, focusing on those whose parents were likely to have ESI.

Taken as a whole, our results suggest that the YA provision led to a decrease in childbearing among all young adult age cohorts, but that the effect may have been particularly strong for 19-23 year olds, with our estimates implying declines of between $6.5 \%$ and $11.1 \%$. Assuming that dependent coverage increased by $30 \%$ among our treatment group (the preferred estimate of Akosa Antwi et al. (2013)), the implied elasticity of childbearing to coverage would be between 0.22 and 0.37 . The YA provision also appears to have led to a decline in marriage 
among 24-25 year olds. Finally, despite the decline in childbearing, tax filing appears to have increased slightly post-reform.

We also find that reductions in fertility were only statistically significant among unmarried young adults (not married young adults), although marriage itself maybe becoming less prevalent as a result of the YA provision - thus, this indicates that either the law lead to less marriage among those who were anyway less inclined to have children soon than other unmarried women, or that the YA provision (perhaps through access to contraception) lead to greater declines in fertility among those who are unmarried. We also find larger reductions among those who already had one child (with a smaller effect among those with no children, and no effect among those with two or more children), and those who were not in post-secondary school, suggesting that there is heterogeneity in impact among young adults.

Some limitations to this study should be noted. First, due to data availability, our preand post-reform periods are limited to two years pre-reform and three years post-reform (through the end of 2013). As a result, whether the effects found here will persist in the long term remains to be seen. Second, the marriage outcome variable is only observed if an individual files a tax return, and we found that return filing increased somewhat post-reform (though the effect is not statistically significant in our main specification), which may bias our marriage estimate somewhat. Third, our proxy for parental insurance coverage is not perfect. Finally, the results found here pertain to one population (young adults with insured parents); whether similar effects will result from other types of insurance expansions is a fruitful topic for future research. 


\section{References}

Abramowitz, J. Forthcoming. "Saying 'I Don't': The Effect of the Affordable Care Act Young Adult Provision on Marriage." Journal of Human Resources.

Abramowitz, J. 2014. "Turning Back the Ticking Clock: The Effect of Increased Affordability of Assisted Reproductive Technology on Women's Marriage Timing." Journal of Population Economics 27: 603-633.

Abramowitz, J. 2016 "Planning Parenthood: The Affordable Care Act Young Adult Provision and Pathways to Fertility" unpublished working paper.

Akosa Antwi, Y., Moriya, A. S., and Simon, K. 2013. "Effects of Federal Policy to Insure Young Adults: Evidence from the 2010 Affordable Care Act Dependent Coverage Mandate." American Economic Journal: Economic Policy 4(4): 1-28.

Barbaresco, S., Courtemanche, C., and Qi, Y. 2015. "Impacts of the Affordable Care Act Dependent Coverage Provision on Health- Related Outcomes of Young Adults." Journal of Health Economics. 40: 54-68.

Braveman, P., Bennett, T., Lewes, C., Egerter, S., and Showstack, J. 1993. "Access to Prenatal Care Following Major Medicaid Eligibility Expansions." Journal of the American Medical Association. 269(10): 1285-1289.

Culwell, K. R., and Feinglass, J. 2007. "The Association of Health Insurance with the Use of Prescription Contraceptives." Perspectives on Sexual and Reproductive Health 39(4): 226-230.

Currie, J., and Gruber, J. 1997. "The Technology of Birth: Health Insurance, Medical Interventions, and Infant Health.” NBER Working Paper 5985.

Dahl, G. 2010. "Early Teen Marriage and Future Poverty.” Demography Vol. 47, No. 3, pp. 689718, August.

Decker, S. L. 2000. "Medicaid, AFDC and Family Formation.” Applied Economics 32(15): 1947-1956.

DeLeire, T., Lopoo, L., and Simon, K. 2011. "Medicaid Expansions and Fertility in the United States." Demography 48(2): 725-47.

Egerter, S, Braveman, P., and Marchi, K. 2002. "Timing of Insurance Coverage and Use of Prenatal Care Among Low-Income Women." American Journal of Public Health 92(3): 423427. 
Goldin, C., and Katz, L. F. 2002. "The Power of the Pill: Oral Contraceptives and Women's Career and Marriage Decisions." Journal of Political Economy 110(4): 730-770.

Kaestner, R. 1999. "Health Insurance, the Quantity and Quality of Prenatal Care, and Infant Health.” Inquiry 36(2): 162-175.

Kaiser Family Foundation. 2008. "Data Note: Rush to the Altar?" URL https://kaiserfamilyfoundation.files.wordpress.com/2013/01/7773datanote.pdf.

Lavelle, B., and Smock, P. J. 2012. "Divorce and Women's Risk of Health Insurance Loss." Journal of Health and Social Behavior 53: 413: 431.

Levine, P., McKnight, R., and Heep, S. 2011. "How Effective are Public Policies to Increase Health Insurance Coverage of Young Adults? American Economic Journal: Economic Policy 3(1): $129-156$

Ma, Jie. "Health Insurance and Birth Outcomes: Evidence from the Affordable Care Act" Unpublished dissertation chapter.

Miller, J. A., Graefe, D. R., and De Jong, G. F. 2013. "Health Insurance Coverage Predicts Lower Childbearing Among Near-Poor Adolescents." Journal of Adolescent Health 53: 749-755.

Mincy, R., Hill, J., and Sinkewicz, M. 2009. "Marriage: Cause or Mere Indicator of Future Earnings Growth? Journal of Policy Analysis and Management 28: 417-439.

Oberg, C. N., Lia-Hoagberg, B., Skovholt, C., Hodkinson, E., Vanman, R. 1991. "Prenatal Care Use and Health Insurance Status." Journal of Health Care for the Poor and Underserved. 2(2): 270-291.

Peters, E., Simon, K., and Taber, J. 2014. "Marital Disruption and Health Insurance." Demography Aug; 51(4): 1397-421.

Sommers, B. D., Buchmueller, T., Decker, S. L., Carey, C., and Kronick, R. 2013. "The Affordable Care Act Has Led To Significant Gains In Health Insurance And Access To Care For Young Adults." Health Affairs 32(1): 165-174.

Strumpf, E. 2010. "Employer-Sponsored Health Insurance for Early Retirees: Impacts on Retirement, Health, and Health Care. Journal of Health Economics 10(2): 105-147.

Yelowitz, A. 1998. "Will Extending Medicaid to Two-Parent Families Encourage Marriage?" The Journal of Human Resources 33(4): 833-865. 
Zimmer, D. M. 2007. "Asymmetric Effects of Marital Separation on Health Insurance among Men and Women. Contemporary Economic Policy 25: 92-106. 


\section{Tables}

Table 1. Sample Statistics

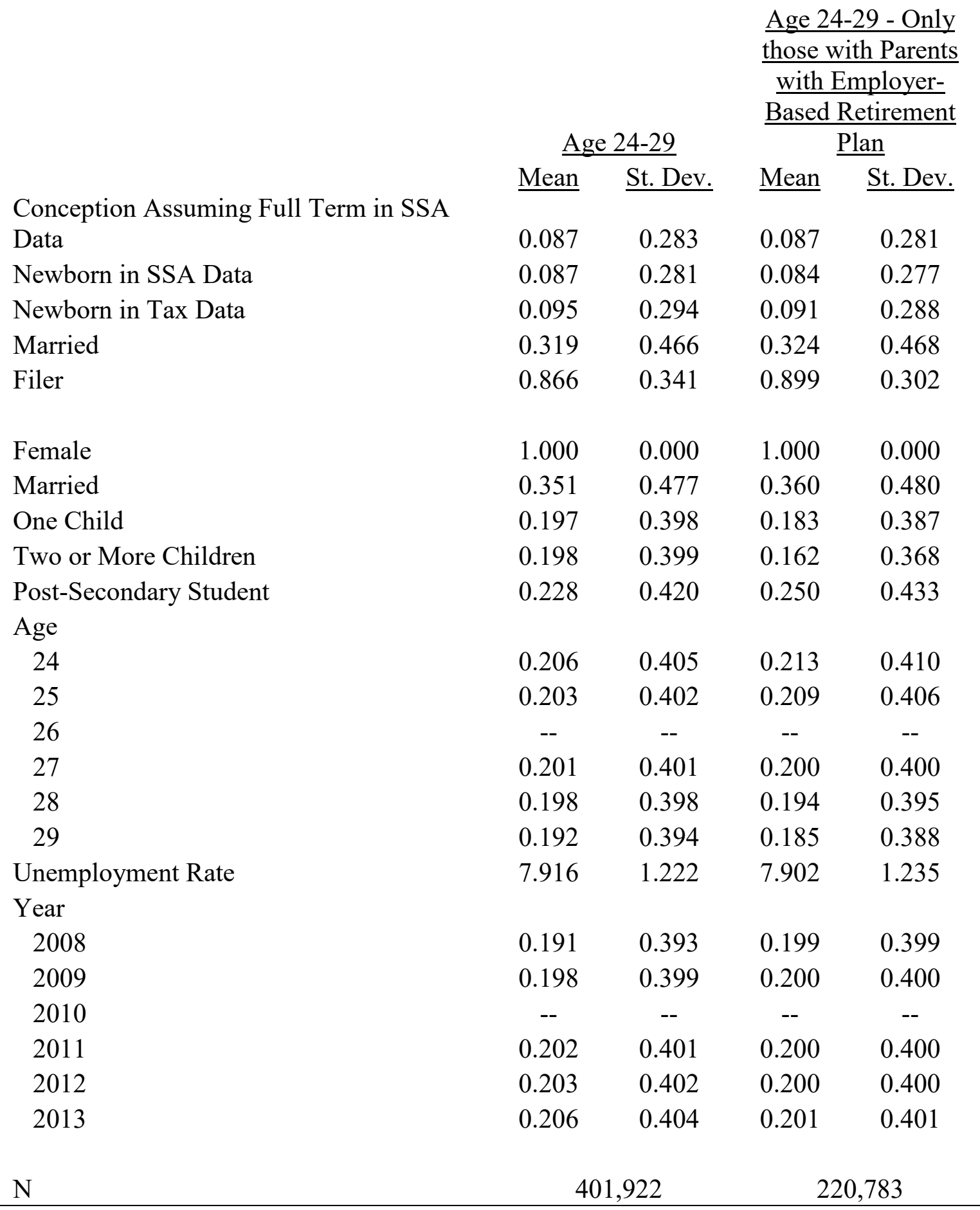

Notes: Data from Internal Revenue Service (IRS) Population of Tax Returns 1\% Sample. The fertility sample includes women only; the marriage sample includes men and women. 
Table 2. Childbearing Estimation Results

\begin{tabular}{|c|c|c|c|}
\hline & $\begin{array}{l}\text { Difference- } \\
\text { in- } \\
\text { Differences } \\
\quad(1)\end{array}$ & $\begin{array}{c}\text { Difference- } \\
\text { in- } \\
\text { Differences } \\
\text { with } \\
\text { Controls } \\
\text { (2) }\end{array}$ & $\begin{array}{c}\text { Difference- } \\
\text { in- } \\
\text { Differences } \\
\text { with } \\
\text { Controls - } \\
\text { only those } \\
\text { with } \\
\text { Parents } \\
\text { with } \\
\text { Employer- } \\
\text { Based } \\
\text { Retirement } \\
\text { Plan } \\
\text { (3) }\end{array}$ \\
\hline A. Conception Assuming Full Term in SSA Data & $\begin{array}{c}-0.004 * \\
(0.002) \\
0.084 \\
401,922 \\
\end{array}$ & $\begin{array}{c}-0.004 * * * \\
(0.001) \\
0.084 \\
401,922 \\
\end{array}$ & $\begin{array}{c}-0.005^{* * *} \\
(0.002) \\
0.077 \\
220,783\end{array}$ \\
\hline B. Newborn in SSA Data & $\begin{array}{c}-0.002 \\
(0.003) \\
0.085 \\
401,922\end{array}$ & $\begin{array}{c}-0.002 \\
(0.001) \\
0.085 \\
401,922\end{array}$ & $\begin{array}{c}-0.002 * \\
(0.001) \\
0.076 \\
220,783\end{array}$ \\
\hline C. Newborn in Tax Data & $\begin{array}{c}-0.004 \\
(0.003) \\
0.099 \\
368,362 \\
\end{array}$ & $\begin{array}{c}-0.004 * * * \\
(0.001) \\
0.099 \\
368,362 \\
\end{array}$ & $\begin{array}{c}-0.003 * \\
(0.001) \\
0.087 \\
206,231 \\
\end{array}$ \\
\hline D. Tax Return Filer & $\begin{array}{c}0.002 \\
(0.006) \\
0.862 \\
401,922\end{array}$ & $\begin{array}{c}0.003 * * * \\
(0.001) \\
0.862 \\
401,922\end{array}$ & $\begin{array}{c}0.002 \\
(0.002) \\
0.893 \\
220,783\end{array}$ \\
\hline
\end{tabular}

Notes: Each cell presents results from a separate regression. Standard errors are in parentheses, and the number of observations is in italics. Control variables include indicator variables for year, age and gender, the unemployment rate, and the interaction between age and the unemployment rate. Standard errors are clustered at the age* year level. Sample includes young adults between the ages of 24 and 29 . *** indicates statistical significance at the $1 \%$ level; ** indicates the $5 \%$ level, and * indicates significance at the $10 \%$ level. 
Table 3. Childbearing Estimation Results - Robustness Checks

\author{
Base Specification - \\ Ages 24-29 \\ Difference-in-Differences - only \\ those with Parents with \\ Employer-Based Retirement Plan
}

(1)

$$
-0.005^{* * *}
$$

0.077

220,783
Ages 19-29

Difference-in-Differences - only

those with Parents with

Employer-Based Retirement Plan

$-0.007 * * *$

(0.001)

0.063

465,256

$\mathrm{N}$

Notes: Model estimated is difference-in-differences with controls in which the sample includes those whose parents had a retirement plan. Each cell presents results from a separate regression. Control variables include indicator variables for year, age and gender, the unemployment rate, and the interaction between age and the unemployment rate. Standard errors are in parentheses, and the number of observations is in italics. Standard errors are clustered at the age* year level. *** indicates statistical significance at the $1 \%$ level; ** indicates the $5 \%$ level, and * indicates significance at the $10 \%$ level 
Table 4. Childbearing Estimation Results - by Gender and Income

\begin{tabular}{|c|c|c|c|c|}
\hline & $\begin{array}{c}\text { Women } \\
\text { (1) }\end{array}$ & $\begin{array}{c}\text { Men } \\
(2)\end{array}$ & $\begin{array}{c}\text { Income < } \\
\text { Median } \\
\text { (3) }\end{array}$ & $\begin{array}{c}\text { Income > } \\
\text { Median } \\
(6)\end{array}$ \\
\hline Treatment*Post & $\begin{array}{c}-0.005 * * * \\
(0.002)\end{array}$ & $\begin{array}{c}-0.002 \\
(0.001)\end{array}$ & $\begin{array}{c}-0.006^{*} \\
(0.003)\end{array}$ & $\begin{array}{c}-0.007 * * * \\
(0.002)\end{array}$ \\
\hline Pre-reform Mean & 0.077 & 0.030 & 0.115 & 0.071 \\
\hline $\mathrm{N}$ & 220,783 & 232,412 & 82,413 & 138,370 \\
\hline
\end{tabular}

Notes: Model estimated is difference-in-differences with controls in which the sample includes those whose parents had a retirement plan. Each cell presents results from a separate regression. Control variables include indicator variables for year, age and gender, the unemployment rate, and the interaction between age and the unemployment rate. Standard errors are in parentheses, and the number of observations is in italics. Standard errors are clustered at the age* year level. Sample includes young adults between the ages of 24 and $29 . * * *$ indicates statistical significance at the $1 \%$ level; ** indicates the $5 \%$ level, and * indicates significance at the $10 \%$ level 
Table 5. Childbearing Estimation Result - by Marital Status, Parity, and Schooling

\begin{tabular}{|c|c|c|c|c|c|c|c|}
\hline & $\begin{array}{c}\text { Not } \\
\text { Married } \\
\text { (1) }\end{array}$ & $\begin{array}{c}\text { Married } \\
\text { (2) }\end{array}$ & $\begin{array}{c}\text { No } \\
\text { Children } \\
(3)\end{array}$ & $\begin{array}{l}\text { One } \\
\text { Child } \\
(4)\end{array}$ & $\begin{array}{l}\text { Two or } \\
\text { More } \\
\text { Children } \\
\text { (5) }\end{array}$ & $\begin{array}{c}\text { Not in } \\
\text { Post- } \\
\text { Secondary } \\
\text { School } \\
(6)\end{array}$ & $\begin{array}{l}\text { Attending } \\
\text { Post- } \\
\text { Secondary } \\
\text { School } \\
\text { (7) }\end{array}$ \\
\hline Treatment*Post & $\begin{array}{c}-0.003 * * \\
(0.001)\end{array}$ & $\begin{array}{c}-0.001 \\
(0.004)\end{array}$ & $\begin{array}{c}-0.003 * * \\
(0.001)\end{array}$ & $\begin{array}{c}-0.008^{*} \\
(0.004)\end{array}$ & $\begin{array}{c}0.001 \\
(0.004)\end{array}$ & $\begin{array}{c}-0.006^{* * *} \\
(0.002)\end{array}$ & $\begin{array}{c}-0.003 \\
(0.003)\end{array}$ \\
\hline Pre-reform Mean & 0.049 & 0.174 & 0.053 & 0.160 & 0.122 & 0.104 & 0.049 \\
\hline $\mathrm{N}$ & 126,888 & 71,517 & 144,675 & 40,433 & 35,675 & 165,504 & 55,279 \\
\hline
\end{tabular}

Notes: Each cell presents results from a separate regression. Standard errors are in parentheses, and the number of observations is in italics. Control variables include indicator variables for year, age and gender, the unemployment rate, and the interaction between age and the unemployment rate. Standard errors are clustered at the age* year level. Sample includes young adults between the ages of 24 and 29 . $* * *$ indicates statistical significance at the $1 \%$ level; ** indicates the $5 \%$ level, and $*$ indicates significance at the $10 \%$ level 
Table 6. Marriage Estimation Results

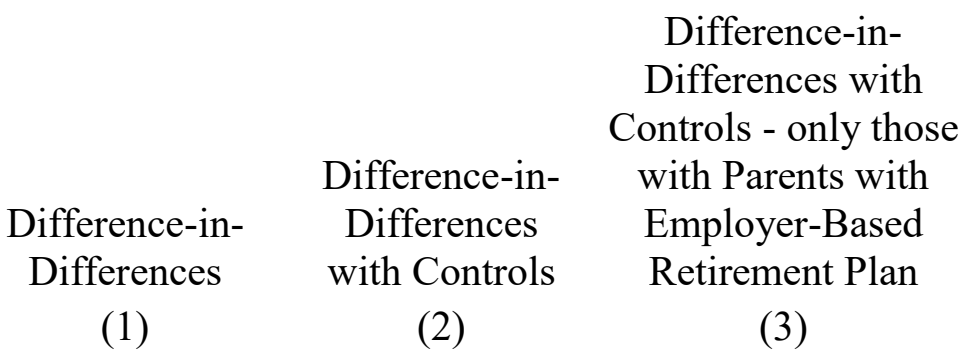

Married in Tax Data

-0.001
$(0.025)$
0.242
683,045

$-0.000$

$-0.005^{* *}$

$(0.002)$

0.239

394,536

Tax Return Filer

$\begin{array}{ccc}0.002 & 0.003 * * * & 0.005^{* * *} \\ (0.005) & (0.001) & (0.001) \\ 0.828 & 0.828 & 0.866 \\ 823,223 & 823,223 & 453,195\end{array}$

Notes: Data from Internal Revenue Service (IRS) Population of Tax Returns 1\% Sample. Model estimated is difference-in-differences with controls in which the sample includes those whose parents had a retirement plan. Each cell presents results from a separate regression. Control variables include indicator variables for year, age and gender, the unemployment rate, and the interaction between age and the unemployment rate. Standard errors are in parentheses, and the mean among the treatment group in the pre-reform period and the number of observations are in italics. Standard errors are clustered at the age* year level. Sample includes young adults between the ages of 24 and 29.

*** indicates statistical significance at the $1 \%$ level; ** indicates the $5 \%$ level, and * indicates significance at the $10 \%$ level

Table 7. Marriage Estimation Results - Expanding Ages in Treatment Group 
Base Specification -

Ages 24-29

Difference-in-

Differences - only

those with Parents

with Employer-

Based Retirement

Plan

(1)

$$
\begin{gathered}
-0.005^{* *} \\
(0.002) \\
0.239
\end{gathered}
$$

394,536
Ages 19-29

Difference-in-

Differences - only

those with Parents

with Employer-

Based Retirement

Plan

(2)

$$
\begin{gathered}
0.008 * * * \\
(0.003) \\
0.133 \\
768,072
\end{gathered}
$$

Notes: Data from Internal Revenue Service (IRS) Population of Tax Returns 1\% Sample. Each cell presents results from a separate regression. Standard errors are in parentheses, and the mean among the treatment group in the pre-reform period and the number of observations are in italics. Control variables include indicator variables for year, age and gender, the unemployment rate, and the interaction between age and the unemployment rate. Standard errors are clustered at the age* year level. Sample includes young adults between the ages of 24 and 29.

*** indicates statistical significance at the $1 \%$ level; ** indicates the $5 \%$ level, and * indicates significance at the $10 \%$ level

Table 8. Marriage Estimation Results - by Gender and Income 


\begin{tabular}{|c|c|c|c|c|c|}
\hline $\begin{array}{l}\text { Men } \\
(1)\end{array}$ & $\begin{array}{c}\text { Women } \\
\text { (2) }\end{array}$ & $\begin{array}{c}\text { Income }< \\
125 \% \mathrm{FPL} \\
\text { (3) }\end{array}$ & $\begin{array}{c}125 \% \text { FPL } \\
<\text { Income < } \\
250 \% \text { FPL } \\
\text { (4) }\end{array}$ & $\begin{array}{c}250 \% \text { FPL } \\
<\text { Income < } \\
400 \% \text { FPL } \\
\text { (5) }\end{array}$ & $\begin{array}{c}\text { Income }> \\
400 \% \text { FPL } \\
(6)\end{array}$ \\
\hline$-0.006^{* *}$ & -0.003 & -0.005 & $-0.016^{* * *}$ & $-0.009 * *$ & -0.003 \\
\hline$(0.003)$ & $(0.003)$ & $(0.007)$ & $(0.004)$ & $(0.003)$ & $(0.003)$ \\
\hline 0.200 & 0.278 & 0.243 & 0.270 & 0.259 & 0.200 \\
\hline 196,131 & 198,405 & 40,959 & 94,049 & 120,445 & 139,083 \\
\hline
\end{tabular}

Notes: Data from Internal Revenue Service (IRS) Population of Tax Returns 1\% Sample. Each cell presents results from a separate regression. Standard errors are in parentheses, and the mean among the treatment group in the pre-reform period and the number of observations are in italics. Control variables include indicator variables for year, age and gender, the unemployment rate, and the interaction between age and the unemployment rate. Standard errors are clustered at the age* year level. Sample includes young adults between the ages of 24 and 29 .

*** indicates statistical significance at the $1 \%$ level; ** indicates the $5 \%$ level, and * indicates significance at the $10 \%$ level 